\title{
Desextranjerizando el Inglés con Memes: \\ Una Propuesta de Alfabetización para las Lecciones de la Escuela Secundaria
}

\author{
Rubens Oliveira Dantas \\ rubens0307@hotmail.com \\ https://orcid.org/0000-0002-7993-592X \\ Universidade Federal Rural do Semi-Árido \\ Mossoró, Brasil. \\ Ananias Agostinho da Silva \\ ananias.silva@ufersa.edu.br \\ https://orcid.org/0000-0001-5442-5133 \\ Universidade Federal Rural do Semi-Árido \\ Angicos, Brasil
}

Recibido: 21/03/2021 Aceptado: 30/09/2021

\section{Resumen}

Para el foco de nuestra investigación, tomamos el meme, en particular, como un género propio del entorno virtual que puede impulsar un trabajo significativo en las clases de inglés, con miras a promover la alfabetización y la des-extranjería del idioma para el alumno. En cuanto al diseño metodológico, este estudio se caracterizó como una investigación cualitativa con sesgo de investigación acción. Se instruyó a los estudiantes a producir memes, con subtítulos en inglés, como una forma de expresar sus sentimientos y opiniones frente a situaciones reales de la vida cotidiana. Obtuvimos un total de 40 memes producidos y publicados en el grupo de WhatsApp y Facebook, involucrando temas que tuvieron repercusión en 2020, especialmente en clases remotas, la pandemia COVID-19 y las elecciones municipales. Por tanto, el resultado de esta intervención de alfabetización pedagógica con el género meme nos mostró la importancia de ver las clases de lengua inglesa como un espacio para la construcción de significados, que interactúa y utiliza contenidos de uso cotidiano por parte de los estudiantes.

Palabras clave: Enseñando. Idioma en Inglés. Desextranjero. Meme. Alfabetizaciones.

\section{Desestrangeirizando o Inglês com Memes: Uma Proposta de Letramentos para Aulas no Ensino Médio}

\section{Resumo}

Para o foco da nossa pesquisa, tomamos o meme, em especial, como um gênero próprio do ambiente virtual que pode impulsionar um trabalho significativo nas aulas de língua inglesa, com vistas a promover letramentos e a desestrangeirização do idioma para o aluno. Em relação ao delineamento metodológico, este estudo caracterizou-se como pesquisa qualitativa com viés de uma pesquisa-ação. Os alunos foram orientados a produzirem memes, com legendas em inglês, como forma de expressar seus sentimentos e opiniões diante de situações reais do cotidiano. Obtivemos um total de 40 memes produzidos e postados em grupo de WhatsApp e Facebook, envolvendo temáticas de repercussão em 2020, sobretudo sobre as aulas remotas, pandemia da Covid-19 e eleições municipais. O resultado dessa intervenção pedagógica de letramentos com o gênero meme nos mostrou a importância de ver as aulas de língua inglesa como espaço de construção de sentidos, que interage e se utiliza de conteúdos de uso diário dos estudantes.

Palavras-chave: Ensino. Língua Inglesa. Desestrangeirização. Meme. Letramentos. 


\title{
Deforeigning English with Memes: Literacies Proposal for High School Lessons
}

\begin{abstract}
For the focus of our research, we take the meme, in particular, as a specific genre to the virtual environment that can boost significant work in English language classes, with a view to promoting literacies and deforeigning the language for the student. Regarding the methodological procedures, this study was characterized as a qualitative research with an action research design. The students were instructed to produce memes, with English subtitles, as a way to express their feelings and opinions in the face of real everyday situations. We obtained a total of 40 memes produced and posted on the WhatsApp and Facebook group, involving themes that had repercussions in 2020, especially on remote classes, the COVID-19 pandemic and municipal elections. Therefore, the result of this pedagogical literacy intervention with the meme genre showed us the importance of seeing English language classes as a space for the construction of meanings, which interacts and uses contents of daily use by students.
\end{abstract}

Keywords: Teaching. English Language. Deforeignization. Meme. Literacies.

\section{INTRODUÇÃO}

Ao longo de anos na docência no ensino de língua inglesa na Educação Básica, temos observado que um grande número dos estudantes alcança à primeira série do Ensino Médio com conhecimento mínimo a respeito da língua inglesa - ainda que tenham estudado a língua durante, pelo menos, quatro anos do Ensino Fundamental - e se depara com um conteúdo programático e livros didáticos distantes da sua realidade e de situações reais de comunicação em inglês.

Percebemos, também, que a língua inglesa, denominada de língua estrangeira (e esse próprio termo já faz associação ao que é estranho e desconhecido) é tomada por esses alunos como uma língua que não lhes pertence. Esse estranhamento pode provocar uma aversão pelo idioma e prejudicar a aprendizagem. De fato, nossa língua materna é o português, porém não podemos ignorar a presença marcante do inglês em diversas situações reais do cotidiano. Por isso, falamos em desestrangeirizar o inglês para o aluno, nos referindo a torná-lo acessível e familiar em seu processo de aprendizagem.

A exemplo disso, percebemos, durante nossa experiência como professores do idioma, que os poucos alunos que apresentam conhecimento básico ou razoável em língua inglesa são aqueles que têm contato diário e preferência por hobbies como músicas internacionais (rock, em especial), videogames e outras atividades culturais que envolvem a língua e fazem parte de seu cotidiano. Ao nosso entender, conforme o aluno se familiariza com a língua estrangeira, ela vai se "desestrangeirizando" e o aluno se familiarizando com 
o que é estranho. Com isso, percebe que o inglês não pertence somente aos outros, mas também a nós brasileiros e a todos que fazem uso dele.

Dado esse contexto, o professor, como mediador de processos de aprendizagem, deve estar atento e preparado para analisar e privilegiar um ensino baseado na realidade desses alunos, geração denominada pelo norte-americano Marc Prensky (2001) como nativos digitais - jovens que possuem identidade virtual, pois passam a maior parte do seu tempo conectados através de redes sociais digitais, blogs, sites, jogos on-line, dentre outras possibilidades de comunicação e entretenimento mediadas pelas tecnologias, sobretudo digitais. Nesses espaços virtuais, cotidianamente, os estudantes se socializam, se expressam criativamente, aprendem e compartilham ideias e novidades.

Nesse ambiente virtual, muitos gêneros surgem e se tornam notórios entre os usuários nativos digitais. É esse o caso do meme, um versátil e moderno gênero textual, com conteúdo irônico ou humorístico, que se manifesta por meio de semioses variadas: imagens (estáticas ou em movimento), bordões, gifs ${ }^{1}$, músicas, fotos, frases, hashtags, entre outras, e é recriado e propagado de maneira incrivelmente acelerada no mundo virtual.

A velocidade com que memes são disseminados (postados ou compartilhados) revela, dentre outras coisas, a sua importância e preferência entre aqueles que interagem no ambiente digital. Como efeito, seu uso pedagógico nas aulas de língua inglesa pode se configurar como uma estratégia de ensino-aprendizagem produtiva. Além disso, são textos que podem fornecer fiéis retratos de valores e problemas de uma sociedade, mas, ao mesmo tempo, provocar o riso pelo humor, proporcionando, assim, prazer e, consequentemente, interesse pela aprendizagem através de uma formação crítica.

Nesta direção, considerando as investigações realizadas acerca da temática, bem como a nossa experiência enquanto docente em aula de língua inglesa, desenvolvemos uma proposta para o ensino significativo do inglês na primeira série no ensino médio, a partir do meme, com vistas a promover o letramento e auxiliar os alunos na desestrangeirização do idioma.

Para isso, apresentamos um panorama sobre o ensino de língua inglesa na escola pública brasileira, considerando os principais documentos que embasam o ensino de Língua Estrangeira Moderna (LEM) no Brasil. Depois, discutimos sobre os memes como um gênero próprio do cenário virtual que pode impulsionar um trabalho significativo nas aulas de língua

\footnotetext{
${ }^{1}$ O GIF (Graphics Interchange Format ou em português formato de intercâmbio gráfico) é um formato de imagem muito usado na internet, que pode compactar várias cenas e, com isso, exibir movimentos, deixando e-mails, redes sociais e blogs mais animados e criativos.
} 
inglesa. Por fim, traçamos o desenho metodológico da pesquisa e, em seguida, realizamos a análise e discussão dos resultados. Tudo isso nos permitiu verificar a validade tanto da teoria aplicada quanto da proposta com os memes produzidos pelos alunos.

\section{O ENSINO DE LÍNGUA INGLESA NA ESCOLA PÚBLICA BRASILEIRA}

A língua inglesa está cada vez mais presente no cotidiano das pessoas. No contexto de uso brasileiro, por exemplo, observamos o emprego de termos dessa língua em simples tarefas

cotidianas: utilizamos a internet, enviamos e-mail, fazemos download de arquivos, jogamos playstation, vamos ao shopping center aos finais de semana, reclamamos do stress, pedimos um deliver, frequentamos fast food, mas desejamos ser fitness. É um vocabulário incorporado ao nosso dia a dia, em atividades que revelam a influência e importância do inglês no mundo. E tudo isso é um reflexo da globalização, que faz do inglês a língua de comunicação mundial, da informática, do turismo, do mercado de trabalho e da ciência.

Em termos pedagógicos, a presença constante do léxico da língua inglesa em situações de interação de falantes do português facilita o reconhecimento do porquê e para $q u e$ estudar inglês no contexto atual. Contudo, o questionamento a respeito de como aprender o idioma é que continua sendo um dilema na educação brasileira, em específico na educação básica em escolas públicas. A busca por métodos e procedimentos de ensino, considerando fundamentos de abordagens teóricas variadas, bem como as diversas reformas curriculares, principalmente por meio de documentos oficiais, vêm provocando mudanças quanto à carga horária, objetivo, conteúdos e à obrigatoriedade da disciplina de língua inglesa na educação básica no Brasil.

Atualmente, os principais documentos oficiais que normatizam e/ou norteiam o ensino dessa língua na educação básica no país podem ser assim listados: a Constituição Federal, que garante o acesso à educação e à universalização do ensino básico; a Lei de Diretrizes e Bases (LDB), que regula a estrutura e define a oferta do ensino em nível nacional, estadual e municipal (BRASIL, 1996); os Parâmetros Curriculares Nacionais $(\mathrm{PCN})$, que orientam as secretarias estaduais e municipais quanto aos conteúdos a serem ensinados (BRASIL, 1998; BRASIL, 2000); a Base Nacional Cumum Curricular (BNCC), que determina, de forma mais detalhada, os conhecimentos e as habilidades essenciais que todos os alunos têm direito de aprender, a cada ano, durante a sua vida escolar (BRASIL, 2018). 
A BNCC não é um currículo, contudo é a base para sua construção. Ela apresenta uma lista de competências e habilidades para que as redes escolares do Brasil construam seus próprios currículos e, dentro de cada currículo, selecione os seus conteúdos. Em consonância com a BNCC, várias mudanças em relação ao ensino de língua inglesa nas escolas brasileiras vêm ocorrendo. Com o Art. $26-\S 5^{\circ}$ da LDB de 1996, que esteve em vigor até o início de 2017, as escolas eram obrigadas a oferecer, na parte diversificada do currículo, a partir do sexto ano, aula de, pelo menos, uma língua estrangeira moderna, a critério da comunidade escolar. Com a Lei $\mathrm{n}^{\circ}$ 13.415, de 16 de fevereiro de 2017, o inglês passa a ser uma língua estrangeira obrigatória em todas as escolas, a partir do sexto ano do ensino fundamental (BRASIL, 2017).

Ainda concernente à língua inglesa, a BNCC traz implicações bastante relevantes para o processo de ensino-aprendizagem da disciplina. Comecemos pela visão geral que o documento apresenta sobre o idioma: o status de uma língua franca. É o que Rajagopalan (2005a; 2009) denomina de World English (Inglês Global), ou seja, uma língua que deixou de ser monopólio de um único país e passou a pertencer, utilizando as palavras do autor, "a todos aqueles que dela fazem uso no seu dia a dia, por mais limitado ou restrito que ele seja (como consultar bibliografia, ouvir músicas, ler manuais de instrução, etc.)” (2009, p. 42), uma prática que dialoga com $\mathrm{o}$ multiculturalismo $\mathrm{e}$ atende às demandas da contemporaneidade, conforme esclarecimento a seguir:

\footnotetext{
Nessa proposta, a língua inglesa não é mais aquela do "estrangeiro", oriundo de países hegemônicos, cujos falantes servem de modelo a ser seguido, nem tampouco trata-se de uma variante da língua inglesa. Nessa perspectiva, são acolhidos e legitimados os usos que dela fazem falantes espalhados no mundo inteiro, com diferentes repertórios linguísticos e culturais, o que possibilita, por exemplo, questionar a visão de que o único inglês "correto" - e a ser ensinado - é aquele falado por estadunidenses ou britânicos (BRASIL, 2017, p. 239).
}

Isso nos propõe um discurso de língua voltado para os princípios de igualdade. No momento em que somos conduzidos a essa ressignificação, encaramos a língua inglesa e o seu ensino de uma outra forma. Atentamo-nos não para um inglês perfeito e uniforme, mas, sim um inglês possível para as situações reais de comunicação. É a ressignificação da ideia de que existe um "inglês melhor" ou um determinado "nível de proficiência" a ser alcançado pelo aluno. A esse respeito, a BNCC observa que:

o status de inglês como língua franca implica deslocá-la de um modelo ideal de falante, considerando a importância da cultura no ensino-aprendizagem da língua 
e buscando romper com aspectos relativos à "correção", "precisão" e "proficiência" linguística (BRASIL, 2017, p. 240).

Durante muito tempo, pensou-se que, para ser falante fluente em inglês seria preciso chegar à perfeição através da repetição sistemática, da imitação do sotaque e da pronúncia de falantes nativos. No mundo contemporâneo, porém, a proficiência ou fluência no idioma vem rompendo essa ideia. Ainda que com pronúncias e cultura diferentes, devemos pensar a língua inglesa como facilitadora da comunicação.

Uma segunda implicação diz respeito ao multiletramento como importante abordagem para o ensino de inglês e sua relação com o mundo globalizado. De acordo com o documento:

saber a língua inglesa potencializa as possibilidades de participação e circulação que aproximam e entrelaçam diferentes semioses e linguagens (verbal, visual, corporal, audiovisual), em um contínuo processo de significação contextualizado, dialógico e ideológico (BRASIL, 2017, p. 240).

O professor precisa compreender que, além do livro didático ou outro tipo de material que ele utiliza em sala de aula para o ensino, os jovens da atualidade têm acesso à tecnologia e às mídias sociais e que, nessas plataformas, muitos gêneros híbridos, potencializados por vários suportes digitais, ampliam as alternativas de letramento. A esse respeito, Santos, Gross e Spalding (2017, p. 123) acreditam que "os letramentos digitais terão de ser concebidos pela escola como uma habilidade essencial para a sua participação no mundo, como instrumentos que podem enriquecer a aprendizagem”.

Outra orientação importante que a BNCC apresenta para a educação de forma geral é que, além do desenvolvimento de competências e habilidades cognitivas, se deve desenvolver as competências e habilidades socioemocionais. Para Saviani (2016, p. 82):

Conforme os documentos legais, a começar pela Constituição Federal e LDB, a
educação tem por finalidade o pleno desenvolvimento da pessoa, o preparo para o
exercício da cidadania e a qualificação para o trabalho. Levando-se em conta que
esses objetivos se referem indistintamente a todos os membros da sociedade
brasileira considerados individualmente, podemos interpretar, com Gramsci
(1975), que o objetivo da educação é conduzir cada indivíduo até a condição de
ser capaz de dirigir e controlar quem dirige.

No componente curricular de língua inglesa não é diferente. Devemos pensar o aluno como ser integral, ou seja, a dimensão cognitiva não pode se desvincular da socioemocional. O professor precisa entender que, além de aluno, aquele sujeito que está ali, em sala de aula, 
é também um cidadão, um futuro profissional, um vizinho, um filho, um irmão. É alguém que também enfrenta dificuldades e problemas. E é necessário estar atento a todas essas situações para atingir os objetivos traçados durante o planejamento, com oportunidades para trabalhar não apenas o idioma propriamente dito, mas também a empatia dos alunos, a cooperação e o trabalho em equipe.

Quando falamos no uso da língua inglesa não se trata necessariamente de valer-se dela para toda a comunicação ordinária do cotidiano, mas de forma paulatina, em contextos mais pontuais, quando ouvimos, lemos, escrevemos e compreendemos textos. Em outras palavras, para aprender uma língua é preciso se inserir em práticas sociais da linguagem: enviar e-mail, compreender a mensagem de um meme nas redes sociais, ler uma notícia de jornal, ouvir uma música, cantar, assistir a um filme, prestar atenção na fala de atores, interagir com os usuários dessa língua. Sobre isso, concordamos com Rajagopalan (2010, p. 11), quando afirma que

a criança só domina uma segunda língua, domesticando-a, domando-a pelo "chifre", enfim trazendo-a pra dentro do seu repertório linguístico. Ou seja, uma língua estrangeira nunca é aprendida como tal, ela precisa ser destituída, esvaziada, de sua "estrangeiridade", livrando-a de qualquer vestígio da sensação de estranheza que ele pode provocar no aprendiz em um primeiro contato.

Enfim, pensar na questão da melhoria do ensino de inglês nas escolas brasileiras é pensar, acima de tudo, nesses jovens que dependem da escola pública para ter igualdade e oportunidade de acesso a culturas, à internet, e/ou ao mercado de trabalho. Portanto, precisamos acabar com o rótulo de que a língua inglesa é um componente curricular de importância secundária e de que aprender o idioma, "dentro desta visão, seria um 'luxo' que está fora do alcance da trajetória de vida esperada para estes jovens" (BRITISH COUNCIL, 2015, p. 18).

\section{OS MEMES: DAS ORIGENS AO USO EM SALA DE AULA}

Hoje, os memes são fenômenos típicos da internet. Apresentam-se de diversas formas e são carregados de muita ironia, criatividade e humor. Eles podem esclarecer dúvidas, mas também confundir os fatos. Tratam sobre os assuntos mais polêmicos da atualidade nas redes sociais, preferencialmente, de uma maneira sucinta, leve, espontânea e até incitam discussões a respeito desses assuntos, adequando-os aos variados níveis sociais ou faixa etária. 
Para alguns pesquisadores, são artefatos culturais e textuais (LIMA; CASTRO, 2016), porém com uma velocidade incrível de replicação e disseminação (SILVA, 2016). São textos recém-chegados ao ambiente escolar, especialmente em alguns livros didáticos mais recentes, mas fazem parte da vida de alunos em ambientes virtuais há alguns poucos anos. Os memes de internet são versáteis e modernos, com conteúdo irônico ou humorístico, e se manifestam por meio de imagens, bordões, gifs, músicas, fotos, frases, hashtags, entre outros artefatos e são recriados e propagados, rapidamente, no mundo virtual. Essa definição é fruto de muitas leituras a respeito do assunto, mas foi em Silva (2016, p. 342) que a nossa compreensão sobre os memes virtuais se revelou com clareza e precisão:

Os memes podem ser formados por imagens, por figuras, fotografias, frases, palavras-chaves ou qualquer outro elemento que apresente um conteúdo irônico ou humorístico que se propague ou se replique na rede. Surgem, replicam-se e transformam-se na rede em uma velocidade impressionante, o que nos permite compará-los a um vírus que se espalha de forma epidêmica, contaminando um número impressionante de pessoas.

Para conhecermos melhor esse elemento virtual, é importante fazer uma retomada de suas origens, partindo do próprio termo. A origem do termo meme é atribuída ao ano de 1976, quando ainda não se ouvia falar na internet que conhecemos hoje. A primeira referência ao termo encontra-se no livro O gene egoísta, de 1976, do biólogo e escritor Richard Dawkins. Na ciência, Dawkins é muito conhecido por ter popularizado a teoria dos genes no processo da evolução humana. Dawkins dizia que os melhores genes eram preservados e retransmitidos de geração para geração, em uma forma de replicação, determinando as nossas características biológicas. É exatamente nesse contexto que ele menciona a palavra meme, uma adaptação do termo grego mimeme, que quer dizer imitação ou algo que é imitado (DAWKINS, 1976):

Precisamos de um nome para o novo replicador, um nome que transmita a ideia de uma unidade de transmissão cultural, ou uma unidade de imitação. "Mimeme" provém de uma raiz grega adequada, mas eu procuro uma palavra mais curta que soe mais ou menos como "gene". Espero que meus amigos classicistas me perdoem se abreviar mimeme para meme (DAWKINS, 1976, p. 330, grifos do autor).

Claro que Dawkins não estava se referindo aos memes que conhecemos atualmente, até mesmo pelo ano em que a obra foi escrita. Mas então, o que foi exatamente que o biólogo chamou de meme? 
Exemplos de memes são melodias, ideias, slogans, as modas no vestuário, as maneiras de fazer potes ou construir arcos. Tal como os genes se propagam no pool gênico saltando de corpo para corpo através dos espermatozoides ou dos óvulos, os memes também se propagam no pool de memes saltando de cérebro para cérebro através de um processo que, num sentido amplo, pode ser chamado de imitação (DAWKINS, 1976, p. 330).

Percebe-se, com esses exemplos, que a ideia do meme é bem mais ampla do que imaginávamos. Dawkins, ao mesmo tempo em que se refere ao gene como um replicador da herança biológica, faz referência ao meme como_um replicador da herança cultural. Isso significa dizer que, para Dawkins, o meme é qualquer tipo de informação que é repassada de geração para geração. A britânica Susan Blackmore (2000), em seu livro The Meme Machine (A Máquina de Meme), avigora esse conceito, quando afirma que "um meme é uma ideia, comportamento, estilo ou uso que se espalha de pessoa para pessoa dentro de uma cultura" (BLACKMORE, 2000, p. 65), tudo isso por meio da imitação.

Assim como o gene se replica de pessoa para pessoa, carregando características físicas (genótipas), o meme replica, de um cérebro para outro, ideias, comportamentos e informações. Nessa visão, ambos são replicadores, mas em circunstâncias diferentes, como esclarece Lima-Neto (2014, p. 111-112), a seguir:

Dawkins entende que tanto os genes quanto os memes são replicadores, mas de ordem diferente. Enquanto os genes se replicam em seres vivos, por meio de uma carga genética repassada via esperma ou óvulos, os memes se replicam de mente em mente, pulando de um cérebro para outro. Os seres humanos, então, seriam máquinas de reprodução de ideias também. Se uma ideia é bem concebida, é eficaz e tem um propósito que pode ajudar uma espécie, ela deve ser imitada e se propaga numa cultura.

Com o advento da internet e a massificação das redes sociais, o termo meme ganhou popularidade. Assim, de acordo com Blackmore (2000, p. 216):

Memes agora podem ser armazenados no disco rígido de um computador em Melbourne e a qualquer momento do dia ou da noite serem copiados, quase sem erros, através de linhas telefônicas ou conexões de satélite, para outro computador em Londres, Florença, Chicago ou Tóquio, usando recurso energéticos de inúmeros seres humanos ao longo do caminho.

Em sua nova versão, o meme, como manifestação imagética, audiovisual e/ou verbal na internet, configura-se como importante estratégia de comunicação para o mundo moderno, ou seja, o meme virtual se tornou prática de uma linguagem propícia para atender a demanda do mundo na contemporaneidade. Em tempos de pós-modernidade, em que se 
correm contra o tempo, as pessoas necessitam de formas mais compactas e objetivas na interação social e na busca por informações.

Essa nova versão do meme, o meme de internet, parece querer suprir essa necessidade. Primeiramente, porque o meme nos atualiza diante dos turbilhões de informações que circulam, tanto nas mídias digitais quanto nos meios de comunicação impressos. Os assuntos mais comentados nas redes sociais, blogs, televisão, rádio, bem como aqueles que estão, há muito tempo, fora de pauta social, podem se resumir ou ser reatualizados em um meme. Em segundo lugar, porque, por trás daquela forma resumida do meme, encontramos mensagens carregadas de ideologias, críticas, opiniões, humor, ironia e sentimentos.

Assim, por exemplo, quando o Conselho Monetário Nacional aprovou a criação da nota de R\$ 200 (duzentos reais), em julho de 2020, diversas especulações começaram a ocorrer a respeito do design da cédula, notadamente da figura que a representaria. Após o anúncio do Banco Central, vários memes surgiram e repercutiram nas redes sociais, sugerindo, de forma crítica e ao mesmo tempo humorística, o design da nova cédula.

Figura 1 - Memes que se originaram da cédula de $\mathrm{R} \$ 200$ (duzentos reais).

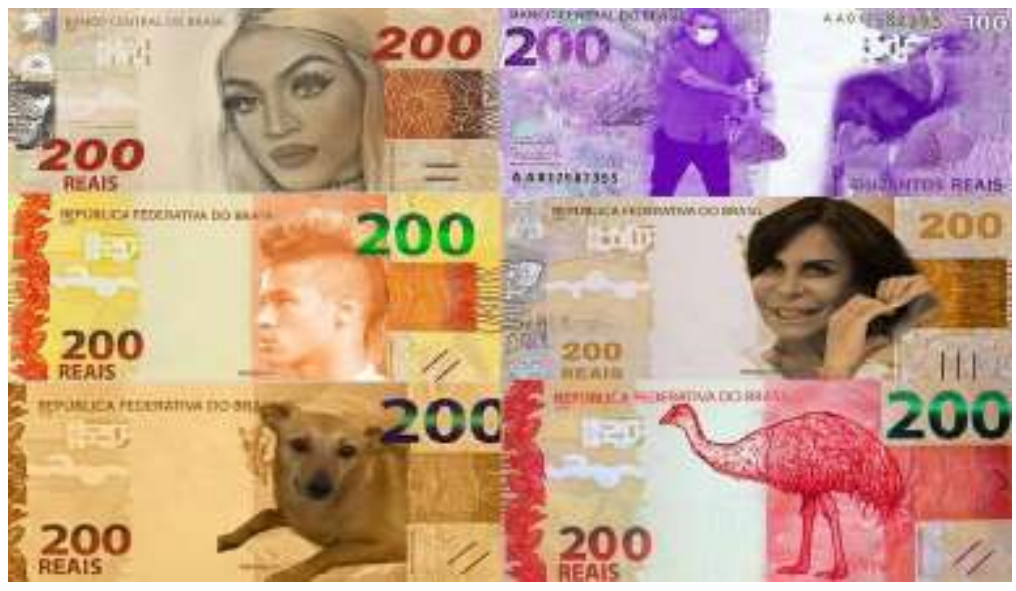

Fonte: Correio 24 horas (2020).

Através desse exemplo da cédula de R $\$ 200$ (duzentos reais), podemos refletir acerca de características peculiares dos memes de internet. Comecemos pelos critérios básicos, da ideia original de meme, que Dawkins (1976), além de outros autores, a exemplo de Recuero (2009), utilizaram para explicar o seu reconhecimento como organismo viral, quais sejam: a) a fidelidade (capacidade em produzir cópias semelhantes ao original) - a exemplo do meme da cédula de $\mathrm{R} \$ 200$ (duzentos reais), todas as ideias e sugestões para a nova cédula partiram das características originais, ou seja, do design proposto pelo Banco Central (BC); 
b) a longevidade (capacidade em permanecer ao longo do tempo) - o meme que tomamos como exemplo está sendo propagado no momento atual e o seu tempo de permanência é indeterminado, ou seja, poderá ser curto ou longo ou até mesmo esse meme poderá ser esquecido e depois voltar a se replicar, uma vez que fica arquivado em bancos de dados na internet por muito tempo; c) a fecundidade (capacidade em gerar cópias) - observemos quantas versões de uma mesma ideia do meme citado como exemplo neste trabalho foi capaz de gerar; e d) alcance (abrangência do meme na rede, que pode ser global ou local) - no caso desse meme que adotamos como exemplo, o seu alcance é global pela grande repercussão a nível nacional e pelo seu envolvimento com diversas grupos e áreas, como a política, artística, econômica, esportiva, assim por diante.

Além dessas características básicas, o exemplo adotado como protótipo revela outras características peculiares nos memes de internet: a) relação com um contexto social - a criação de uma cédula devido à crise econômica do Brasil causada pela pandemia; b) materializa-se sob uma forma visível de apresentação - o design da cédula de R\$ 200 (duzentos reais); c) originou-se em redes sociais, mas sua repercussão ganhou uma dimensão além do ambiente virtual - a manifestação de apoio de um parlamentar por meio de um abaixo assinado; d) estimulou o interesse dos internautas em querer compartilhar ou até mesmo produzir outras versões - não somente por ser engraçado, mas também por envolver formas de apreciação, afeto, críticas e julgamento, no caso da sensibilidade em defesa e luta contra os maus tratos de animais e a crítica às atitudes do governo atual; e) o conteúdo se apresentou como texto e se constituiu, a partir de situações de comunicação, envolvendo assuntos como politica, futebol, sexualidade, causas animais, entre outros - indícios que revelam o meme como um versátil e moderno gênero discursivo.

Outra característica dos memes que não pode ser ignorada é sua relação dialógica e de intertextualidade no processo de comunicação. De acordo com Cavalcante e Oliveira (2019), a intertextualidade, assim como a viralização, é critério constitutivo da produção de memes, porque todo meme necessariamente implicará a sua relação com um texto-fonte, seja pela copresença (por meio de citação, paráfrase, referência, alusão), seja pela derivação de um texto em outro (paródia e adaptações) ou por ambas. Tomando como referência Silva (2016, p. 352), entendemos que

Todo meme rememora outros memes (e também outros gêneros), porque com eles dialoga: seja por meio do estilo, da estrutura composicional, do conteúdo temático (elementos característicos do gênero - relações dialógicas intergêneros) ou mesmo pelo fato de ser atravessado constitutivamente por outros discursos, por outras 
vozes que representam diferentes lugares sociais que se estabilizam e se desestabilizam durante o processo de replicação (SILVA, 2016, p. 352).

Eles dialogam entre si e nós dialogamos com eles. Uma vez que compartilhamos e comentamos um meme nas redes sociais, estamos concordando ou discordando e, muitas vezes, argumentando a favor ou contra o ponto de vista da informação transmitida. No site do Facebook, por exemplo, além de curtir, para demonstrar afeição com a informação, temos mais cinco reações de emojis ${ }^{2}$ em forma botão: Amei, Haha, Uau, Triste e Grr, ativados para demonstrar, respectivamente, que amou, sorriu, admirou-se, entristeceu-se ou se chateou com o que foi postado.

Entretanto, ao que nos parece, apesar de tão popular entre adolescentes e jovens, os memes têm passado quase despercebidos como instrumento a ser utilizado pelo professor em sala de aula. Apesar de algumas pesquisas existentes acerca de seu uso nos processos de ensino-aprendizagem, sentimos sua falta nos livros didáticos, nas temáticas discutidas nos encontros pedagógicos e, sobretudo, nos planos de aula de professores. Os memes fazem parte do cotidiano dos alunos e, conforme os Parâmetros Curriculares Nacionais, "cabe à escola viabilizar o acesso do aluno ao universo dos textos que circulam socialmente, ensinar a produzi-los e a interpretá-los" (BRASIL, 1997, p. 26).

Outra justificativa pedagógica para utilização de memes em sala de aula é que eles se configuram como uma prática linguageira contemporânea. Suas múltiplas faces constituídas de sons, imagens estáticas e em movimento, bem como a sua forma popular e criativa de refletir e discutir opiniões, ideologias e assuntos pessoais e públicos, fazem do meme um dos textos mais produzidos, replicados, lidos e acessados nas interações, sobretudo entre as pessoas mais jovens, em redes sociais e até mesmo, em algumas situações, fora do ambiente virtual. De acordo com a BNCC, “as práticas de linguagem contemporâneas não só envolvem novos gêneros e textos cada vez mais multissemióticos e multimidiáticos, como também novas formas de produzir, de configurar, de disponibilizar, de replicar e de interagir" (BRASIL, 2017, p. 66).

Além de se configurar como prática linguageira de fácil acesso e compreensão pelos usuários e, portanto, pelos alunos no espaço pedagógico, os memes podem possibilitar

criar laços, ainda que difusos, entre as pessoas: reelaborar um "meme" é ser parte de uma comunidade talvez anônima, mas não menos forte. "Memes" são compartilhados em redes sociais digitais, de certa maneira, pelo mesmo motivo

\footnotetext{
${ }^{2}$ Emojis são pequenas imagens, símbolos gráficos e carinhas usados em mensagens eletrônicas e páginas da internet para expressar emoções e transmitir informações sucintas.
} 
que pessoas contam piadas ou histórias que ouviram: para fazer parte do grupo (MARTINO, 2015, p. 483).

Os memes "criam laços" não somente entre pessoas, mas também possuem potencial interativo com outras mídias. Segundo Souza (2013, p. 131):

no ciberespaço os "memes" têm a ver principalmente com comentários, postagens de fotos, vídeos, paródias que são comumente relacionados a notícias do cotidiano provenientes em grande parte de outros canais midiáticos, sendo estes a televisão, os jornais impressos e o rádio.

Finalmente, outra reflexão acerca que pode ser feita a partir do uso pedagógico dos memes é sobre o compromisso ético nas redes sociais. A propagação das chamadas fakenews, frases preconceituosas, comentários ofensivos ou indevidos e os discursos de ódio nos dão sempre a impressão equivocada de que a internet ainda é uma terra sem lei, onde não se há limite, respeito e aceitação de opiniões alheias. A propósito disso, a BNCC sugere:

contemplar de forma crítica essas novas práticas de linguagem e produções, não só na perspectiva de atender às muitas demandas sociais que convergem para um uso qualificado e ético das TDIC - necessário para o mundo do trabalho, para estudar, para a vida cotidiana etc. - , mas de também fomentar o debate e outras demandas sociais que cercam essas práticas e usos. É preciso saber reconhecer os discursos de ódio, refletir sobre os limites entre liberdade de expressão e ataque a direitos, aprender a debater ideias, considerando posições e argumentos contrários (BRASIL, 2017, p. 67).

Dessa forma, os memes podem ser elementos importantes de análise para que a escola possa refletir sobre questões que se distanciem de um comportamento ético. Esse aluno da contemporaneidade é o jovem que necessita lidar com as mais diversas situações da vida, compreender e respeitar a diversidade e aprender a lidar com as suas próprias emoções.

Acreditamos, portanto, que os memes, provocadores de importantes reflexões, podem contribuir expressivamente para o aprendizado em sala de aula, nos mais diversos contextos de interação, de produção de discursos e inclusão social. Nesse sentido, é imprescindível que os alunos consigam, tendo consciência do potencial de sentidos a que esses textos se prestam, utilizar a língua para atingir a seus mais diversos propósitos, em quaisquer que sejam as circunstâncias em que estão interagindo. Daí a necessidade de as aulas de inglês serem vistas como espaço de construção de sentidos e não apenas como lugar de sistematização de regras e nomenclaturas de uma gramática que se torna prescritiva em vez de produtiva. 


\section{A CONJUNTURA DA PESQUISA}

Ao refletirmos sobre a problemática que envolve o ensino de idiomas, sobretudo de língua inglesa, nas escolas públicas brasileiras e das exigências postas diante de um mundo globalizado, fatores esses que refletem a nossa prática diária como professor na educação básica, causando-nos uma preocupação com a qualidade e com os resultados das aulas ministradas, resolvemos desenvolver uma proposta de letramento com memes, na qualidade de gêneros digitais próprios do cenário virtual que podem impulsionar um trabalho significativo nas aulas de inglês.

Sob o ponto de vista da forma como abordamos o problema, este estudo caracterizase como pesquisa qualitativa. De acordo com Flick (2009, p. 9), “A pesquisa qualitativa acontece no mundo real com o propósito de 'compreender, descrever e, algumas vezes, explicar fenômenos sociais, a partir de seu interior, de diferentes formas"”. Paiva (2019, p. 14) afirma que "tais formas incluem análise de experiências individuais ou coletivas, de interações, de documentos (textos, imagens, filmes ou músicas), etc.

Acerca da metodologia, realizamos uma pesquisa-ação que, segundo Burns (2009a, p. 289), "é a combinação e interação de dois modos de atividade - ação e pesquisa”. Assim, em face dessa combinação e de outras características, acreditamos que esse tipo de pesquisa reúne as condições básicas para uma reflexão e, consequentemente, para provocar mudanças na prática do processo de aprendizagem dos envolvidos. Havia um problema prático a ser resolvido, que era a fragilidade no ensino de língua inglesa no ensino médio de uma escola pública e, ao nosso entender, o uso dos memes em sala de aula poderia ser uma alternativa para amenizar essa situação.

Por conseguinte, a pesquisa-ação atendeu, consideravelmente, a essa necessidade, uma vez que esse tipo de pesquisa, segundo Paiva (2019, p. 72), "se caracteriza pela intervenção em busca de mudanças positivas em determinado contexto" e os seus aspectos apontam para o reconhecimento da capacidade de as pessoas, vivendo e trabalhando em determinado contexto, participarem ativamente, e em todos os aspectos, do processo de pesquisa; propósito da pesquisa conduzida pelos participantes de melhorar as práticas e seus contextos pelos próprios participantes (KEMMIS; MCTAGGART, 1988).

O projeto foi desenvolvido em uma escola estadual do interior do Rio Grande do Norte no Brasil. Em comum acordo entre equipe pedagógica e a professora de língua inglesa das turmas de primeiras séries, foi-nos sugerido a $1^{\mathrm{a}}$ série $\mathrm{D}$, com 22 alunos, na faixa etária 
entre 14 e 18 anos, cujo diferencial, em relação às outras turmas, estaria no feedback, que a turma sempre dava, nas atividades realizadas na disciplina de língua inglesa.

Aos alunos estava designada a tarefa de criar memes como forma de expressar seus sentimentos e opiniões sobre assuntos da atualidade. A nós, enquanto pesquisadores, estava a incumbência de analisar essas produções, a partir das quais os alunos poderiam desenvolver uma competência comunicativa por meio da escrita e compreensão do idioma trabalhado, associando o imagético com o verbal, apropriando-se de seu conhecimento prévio, bem como da intertextualidade de assuntos que fazem parte de seu cotidiano.

Nesse sentido, para construirmos os dados que precisávamos, foi necessário utilizar alguns instrumentos digitais, como plataformas, sites, aplicativos de mensagens instantâneas e redes sociais, bem como desenvolver alguns procedimentos, conforme descrevemos a seguir.

Por consequência da pandemia da COVID-19, as plataformas digitais foram as nossas grandes aliadas e uma alternativa para a realização dos encontros com os alunos de forma remota. A escola onde desenvolvemos esta pesquisa estava adotando a plataforma do Google Meet e o aplicativo de WhatsApp para suas aulas remotas. Mantivemos essas mesmas plataformas e criamos, além do grupo de WhatsApp da turma, o Speak Up!, grupo específico para intensificar a comunicação com a turma e realizar as primeiras ações de nosso projeto, que envolviam produção, interpretação, e correção dos memes produzidos.

Primeiramente, foi necessário discutir com os 22 alunos a função comunicativa dos memes para que eles pudessem compreender a essência de nosso trabalho e, a partir de então, produzir e compartilhar suas produções, expressando-se sobre assuntos do cotidiano. Para a produção dos memes, os alunos utilizaram seus próprios smarthphones e os sites imgflip.com, imgur.com/memegen, livememe.com, makeameme.org e memegenerator.net/create, criadores de memes gratuitos, práticos e com extenso banco de imagens, o que aumentaria as opções de ideias bem como a criatividade na elaboração de memes.

Assim, a nossa orientação inicial foi apresentada para eles da seguinte forma: 
Figura 2 - Enunciado para produção dos trabalhos.

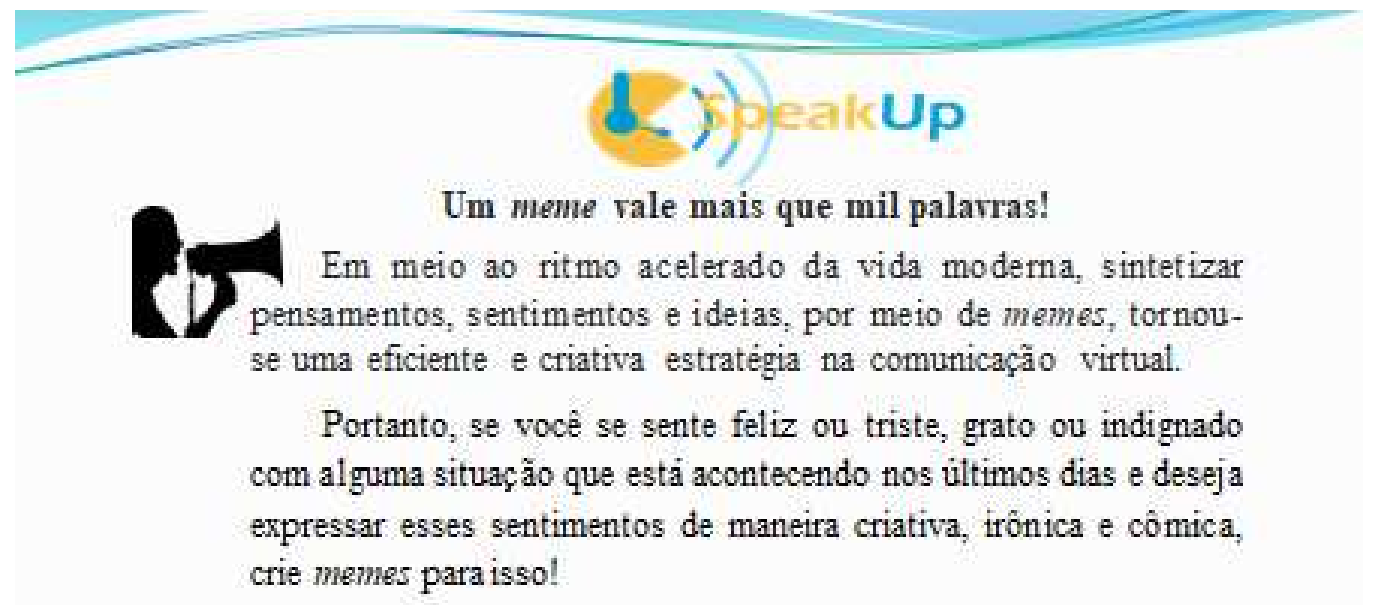

Fonte: Speak Up (2020).

Escolhemos o grupo de WhatsApp Speak Up! para trabalhar as primeiras produções, por ser um grupo exclusivo da turma e, assim, sendo uma etapa de experiência inicial, poderíamos realizar um trabalho de análise, correção e aperfeiçoamento das produções dos alunos antes de compartilhá-las com outras pessoas.

Sugerimos aos alunos que cada um produzisse pelo menos dois memes. Obtivemos um total de 44 memes produzidos e postados no grupo, envolvendo diversas temáticas, sobretudo a respeito das aulas remotas, pandemia da Covid-19 e eleições municipais 2020 três dos principais assuntos em pauta naquele momento no Brasil.

À medida que os memes iam sendo postados no grupo, observávamos a relação que os alunos faziam entre imagens e legendas, incoerência em alguns textos, erros de digitação, grafia e expressões ou palavras mal empregadas e, logo após, dávamos um feedback, na maioria das vezes no WhatsApp, em contato privado, para que pudessem melhorar suas produções.

Apesar dessas necessidades de ajustes, de uma forma geral, os memes estavam bem produzidos, criativos e atenderam muito bem às necessidades de comunicação dos alunos. Diante disso, abrimos espaço para que eles opinassem e discutissem a respeito das mensagens transmitidas pelos memes.

Após esses momentos de postagens e discussões no WhatsApp, partimos para a segunda etapa que consistiu em criar um grupo no Facebook e nele compartilhar os memes produzidos para uma abrangência extra sala de aula. Entendemos o Facebook como relevante espaço para publicação do trabalho de produção dos alunos, porque era a rede social que eles mais usavam e, depois, por ser uma das formas mais evidentes de que os memes teriam maior possibilidade de assumir uma de suas principais características, a 
viralização, ou seja, outras pessoas poderiam ter acesso, curtir, comentar e compartilhar os trabalhos desenvolvidos pelos alunos.

A propósito, diante do trabalho desenvolvido (memes produzidos, compartilhados, curtidos, comentados, discutidos no grupo de WhatsApp e publicados no grupo de Facebook), compreendemos, na prática, o quanto os memes refletem a vida real dos alunos. Com efeito, eles souberam aproveitar seus conhecimentos prévios na interpretação e compreensão dos memes, intertextualizando suas produções com aquilo que faz parte de seu cotidiano e identificaram a ideia central de cada texto produzido pelos colegas, sem a necessidade de estar traduzindo as legendas para a língua materna, associando o imagético com o verbal.

\section{ANÁLISE E DISCUSSÃO DOS RESULTADOS}

Em nossa intervenção, recomendamos aos alunos que cada um produzisse pelo menos dois memes, com legendas em língua inglesa, para expressar seus sentimentos e opiniões sobre situações vivenciadas na atualidade. Para uma análise mais precisa dessas observações, dos quarenta memes produzidos pelos alunos, escolhemos quatro como amostra representativa que comprovou a sua eficácia como instrumento de letramento em aulas de língua inglesa. Por questões éticas de pesquisas, identificamos os alunos com nomes fictícios. Os critérios de afunilamento das amostras foram a repercussão nas discussões, curtidas, comentários e compartilhamentos, tanto no grupo de WhatsApp quanto na rede social Facebook.

Os memes serviram como espécie de tribuna para os jovens se expressarem ou como uma espécie de blow the whistle - traduzido pela expressão idiomática em língua portuguesa pôr a boca no trombone. De fato, queríamos que o idioma fosse tomado em situações de uso real, ou seja, retomar situações do cotidiano dos jovens nos processos de aprendizagem na disciplina de língua inglesa. Usando as palavras de Faraco (2007, p. 13), “o que buscamos são procedimentos que, na prática, auxiliem, contribuam, acrescentem subsídios ao ensino e aprendizagem de língua, como modo de promover a integração do conhecimento".

Começamos as atividades de intervenção pedagógica em outubro de 2020, sendo todas desenvolvidas na modalidade remota, considerando medidas de distanciamento social ditadas pelo estado de calamidade pública no país provocado pela pandemia do novo coronavírus. Por outro lado, estávamos às vésperas das eleições municipais de 2020. Em 
síntese, esses eram os assuntos mais comentados em conversas entre membros da família, amigos e nas diversas mídias de comunicação, sobretudo nas redes sociais.

\subsection{MEME SOBRE AULAS REMOTAS}

Os alunos estavam vivenciando um ano atípico, o que potencializou tensão, incertezas e desafios peculiares dessa fase da vida humana. Muitos deles se sentiam até silenciados e invisíveis diante desse cenário, sobretudo desde o momento em que foram surpreendidos com a determinação para o funcionamento de aulas remotas durante a pandemia da Covid-19, sem que fossem consultados a respeito, sem que fossem consideradas suas especificidades sociais, econômicas, culturais, enfim. Essa situação foi observada em diversos dos textos produzidos pelos alunos, como no meme a seguir, produzido por uma das alunas da turma.

Figura 3 - Meme sobre aulas remotas

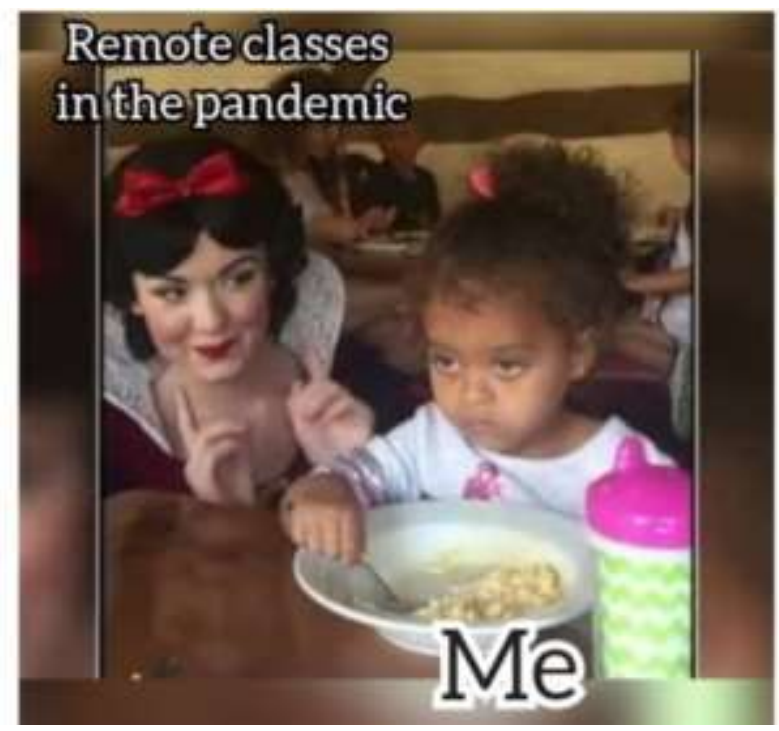

Fonte: Produção dos alunos (2020).

A imagem selecionada pela aluna Regina é de um vídeo compartilhado e viralizado no YouTube em 2017. Na cena, gravada durante visita a um parque temático Disney, uma menina chamada Kaylin está fazendo uma refeição quando uma mulher fantasiada de Branca de Neve pede para que ela sorria. Além de ignorar a personagem, a criança aparece séria, demostrando indiferença ou completa insatisfação com a situação. A princesa é persistente e insiste, mas a menina permanece apática. Ainda que os contos de fadas encantem as crianças, sendo as meninas, sobretudo, muitas vezes, inspiradas pelas princesas, de modo 
que conhecer uma delas (ou a sua personificação) seria o sonho de qualquer garota, não é isso que ocorre com Kaylin, que se demonstrou indiferente e até não grata com a presença de Branca de Neve.

Ora, foi o ineditismo desta situação, o inusitado que despontou o flagrante deste acontecimento como um meme. Na verdade, essa é uma das condições para que um fato cotidiano possa se tornar um meme. Podemos citar, como outro exemplo disso, um vídeo compartilhado nas redes sociais, especialmente no Brasil, em novembro de 2015, em que ocorre uma briga protagonizada por duas adolescentes, nas proximidades da escola onde estudavam. A cena termina com uma das adolescentes, de forma inesperada, exclamando a frase que repercutiu virtualmente e, consequentemente, "virou meme": Já acabou, Jéssica?.

A briga entre essas duas adolescentes, uma prática comum entre os jovens dessa faixa etária, ainda que não politicamente correta, certamente não foi o evento deflagrador do meme. Mas essas três palavras ditas de forma inesperada foram suficientes para levar os estudantes, que assistiam a cena ao redor das meninas, à euforia. Foi essa ruptura com a normalidade, com o corriqueiro que fez com que o evento ganhasse repercussão e despontasse o flagrante desse acontecimento como um meme.

Como se constata, o meme da figura 3 tem como tema as aulas remotas. A aluna manifestou a insatisfação em relação ao novo modelo de ensino adotado durante o isolamento social em meio à pandemia da Covid-19. Poderíamos alegar que as aulas no formato remoto pudessem ser uma boa estratégia de interesse para os alunos. Afinal de contas, eles poderiam ter a comodidade de estudar onde e como quisessem (computador, celular, tablet); interagir com os colegas de sala por meio de chats, plataformas, grupos, comunidades; ter mais tempo livre e, além de tudo, estar em um de seus espaços preferidos, os ambientes digitais.

Mas, conforme se depreende do meme da aluna Regina, a realidade era de insatisfação. Esta circunstância havia sido diagnosticada e relatada em um portfólio produzido pela escola, com dados, questionários e gráficos, explorados em capítulos anteriores neste trabalho. Essa estudante, simplesmente, sintetizou por meio de um meme: a) a baixa frequência dos alunos nas aulas remotas, alguns por não possuírem aparelho celular, outros por não terem acesso a computadores e internet de qualidade; e, uma boa parte dos alunos, por residirem em comunidades rurais, onde o sinal de internet não funciona devidamente; b) o questionário realizado para os alunos, que se autoavaliaram insatisfeitos quanto ao seu rendimento no novo formato de ensino e não acreditavam em aprendizagem significativa por meio de mídias digitais. 
Quanto aos aspectos linguísticos (estilo verbal) empregados no meme da figura 3, a aluna utilizou dois enunciados para identificar os personagens de acordo com a construção de sentido do texto. O primeiro, remote classes in the pandemic (aulas remotas na pandemia), é personificado pela figura de Branca de Neve. O segundo, o pronome me (eu), está representado pela garota. O pronome me, nesse caso, é uma elipse da expressão it's me (sou eu), ou seja, é o uso informal da língua. Sabemos que os memes possuem essa característica, utilizam-se da informalidade, frases curtas e até palavras abreviadas como uma forma de tornar a comunicação virtual mais ágil e prática.

Assim, entendemos que linguagem coloquial ou informal é o uso da língua em situações cotidianas para atender às necessidades de comunicação imediata e em tempo real. Ela é empregada nas conversas descontraídas e espontâneas, nos chats e mensagens de aplicativos de relacionamentos, charges, tirinhas, memes, entre outros gêneros. De acordo com Bakhtin (1997, p. 301), "não a aprendemos nos dicionários e nas gramáticas, nós a adquirimos mediante enunciados concretos que ouvimos e reproduzimos durante a comunicação verbal viva que se efetua com os indivíduos que nos rodeiam”.

Em se tratando da construção composicional, um dos elementos que fazem com que os sujeitos reconheçam o padrão de gênero, o meme da figura 3 foi produzido com a imagem de um vídeo compartilhado e viralizado no YouTube em conexão com curtos enunciados que relacionam os personagens da imagem às situações de domínio de sentido em que se ocupa o texto, "[...] ao que a teoria textual chama de "(macro/super) estrutura" do texto, à progressão temática, à coerência e coesão do texto" (ROJO; BARBOSA, 2015, p. 94).

\subsection{MEME SOBRE DILEMA DE JOVENS DURANTE A QUARENTENA}

Outro tema abordado pelos alunos em suas produções foi a pandemia da Covid-19. Por mais que não pertencessem a grupos de risco, os jovens envolvidos nesta pesquisa revelaram preocupação e medo em relação à pandemia do novo coronavírus. $\mathrm{O}$ sentimento parecia ser de tristeza, pela morte de familiares e amigos bem próximos, e de muitas incertezas, dúvidas e dilemas, conforme vemos no meme da figura 4. 
Figura 4 -Meme sobre quarentena da pandemia do novo coronavírus.
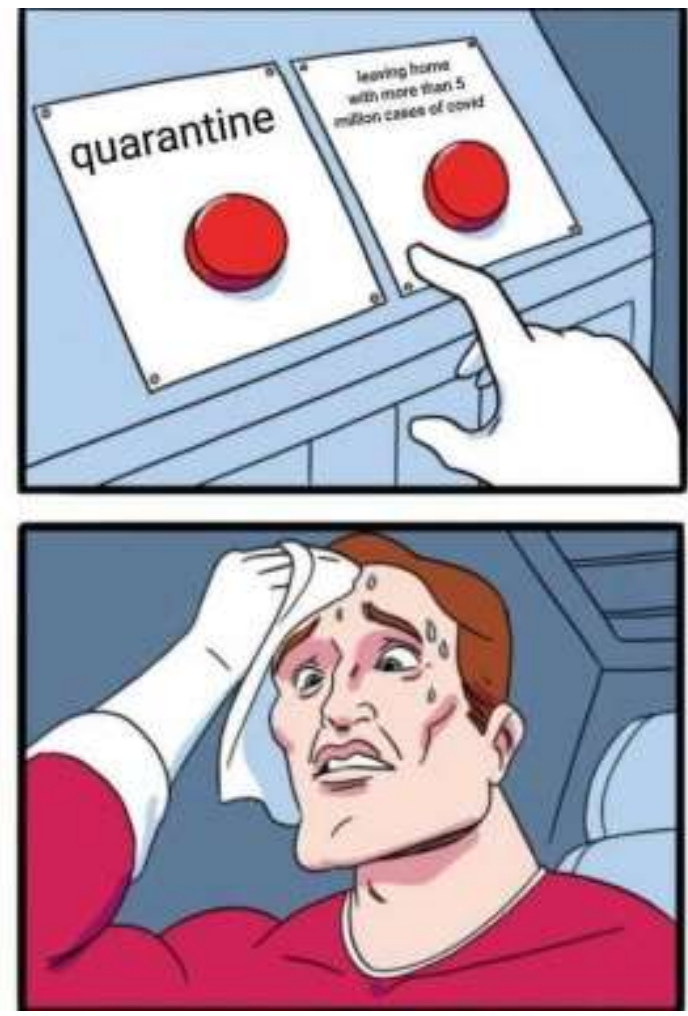

Fonte: Produção dos alunos (2020).

A imagem escolhida por Júlia, uma ilustração bem conhecida entre os que se utilizam de memes em redes sociais, retrata muito bem uma situação de extrema indecisão. Vê-se o desenho de um homem, em estado emocional de aflição ao se deparar diante de um painel com duas alternativas. Esse é um meme que está sendo sempre utilizado para revelar o quanto é difícil fazer escolhas na vida. No caso da aluna Júlia, obedecer ao isolamento social ou sair de casa para se divertir.

Em tempos de pandemia, a Organização Mundial de Saúde e, posteriormente, o Ministério da Saúde fizeram uma série de recomendações para o enfrentamento do novo coronavírus. Além disso, governadores e prefeitos em diferentes regiões do Brasil anunciaram a quarentena como uma medida de prevenção para conter a disseminação do vírus. Essas recomendações e determinações foram amplamente divulgadas na mídia, que cumpria o seu papel na disseminação de informações.

Todavia, diferentemente do que aconteceu em vários outros países, havia um dilema no Brasil relacionado à credibilidade dessas informações, colocadas em dúvidas pelo próprio presidente da República, Jair Messias Bolsonaro (SEM PARTIDO). Teve início no país uma guerra de (des)informações: divergências entre confiar ou não nas informações divulgadas pelos meios de comunicação, dúvidas quanto à eficácia de uso de máscaras e medicamentos 
alternativos, desarmonia entre as orientações da OMS e os depoimentos do presidente da República.

Falavam-se em grupos de riscos, em priorizar idosos e pessoas com comorbidades, redobravam a atenção com crianças, orientavam os adultos. E quanto aos adolescentes? O que se dizia era que eles eram praticamente imunes, assintomáticos ao vírus, mas que precisavam se isolar para proteger seus pais, avós ou demais familiares que fizessem parte de grupos de risco. Assim, de um lado estava a responsabilidade em proteger seus entes queridos, do outro, as necessidades inerentes à faixa etária: situação hormonal e emocional, necessidade em controlar a ansiedade, baladas, encontros com amigos, paqueras e namoros, preocupação com Exame Nacional do Ensino Médio (ENEM), entre outras.

Portanto, "quarentine" (quarentena) ou "leaving home with more than 5 million cases of covid" (sair de casa com mais de cinco milhões de casos de Covid-19) era o dilema de Júlia, que representava não só sua turma colegial, mas muitos dos adolescentes que se viam diante desse impasse.

Por utilizar palavras muito parecidas com suas traduções em língua portuguesa, o que denominamos de palavras cognatas ${ }^{3}$, o meme da figura 4 foi configurado com um estilo verbal de fácil compreensão. É como se estivéssemos mesmo familiarizados com a língua inglesa, esvaziando-a de sua estrangeiridade (RAJAGOPALAN, 2011).

\subsection{MEME SOBRE O NOVO CORONAVÍRUS X ELEIÇÕES MUNICIPAIS DE 2020}

À medida que os dias foram passando, aproximava-se um outro cenário no contexto nacional: as campanhas eleitorais de 2020. No caso de Assú/RN, a cidade se encontrava em "pé de guerra", aparentemente, não mais contra o coronavírus, mas resultante da disputa entre candidatos a prefeito e vereadores para exercerem os mandatos no período de 2021 a 2024.

Por conseguinte, observamos nas produções dos alunos críticas bastante pertinentes sobre o descaso com a pandemia do novo coronavírus, em função das campanhas eleitorais do município, como bem revela o meme a seguir, produzido pelo aluno denominado de Pedro.

Figura 5 - Meme sobre o novo coronavírus x eleições municipais de 2020.

\footnotetext{
${ }^{3}$ Cognatas são palavras que possuem a mesma raiz ou origem etimológica que outra e que, geralmente, são muito parecidas tanto na escrita quanto no significado.
} 


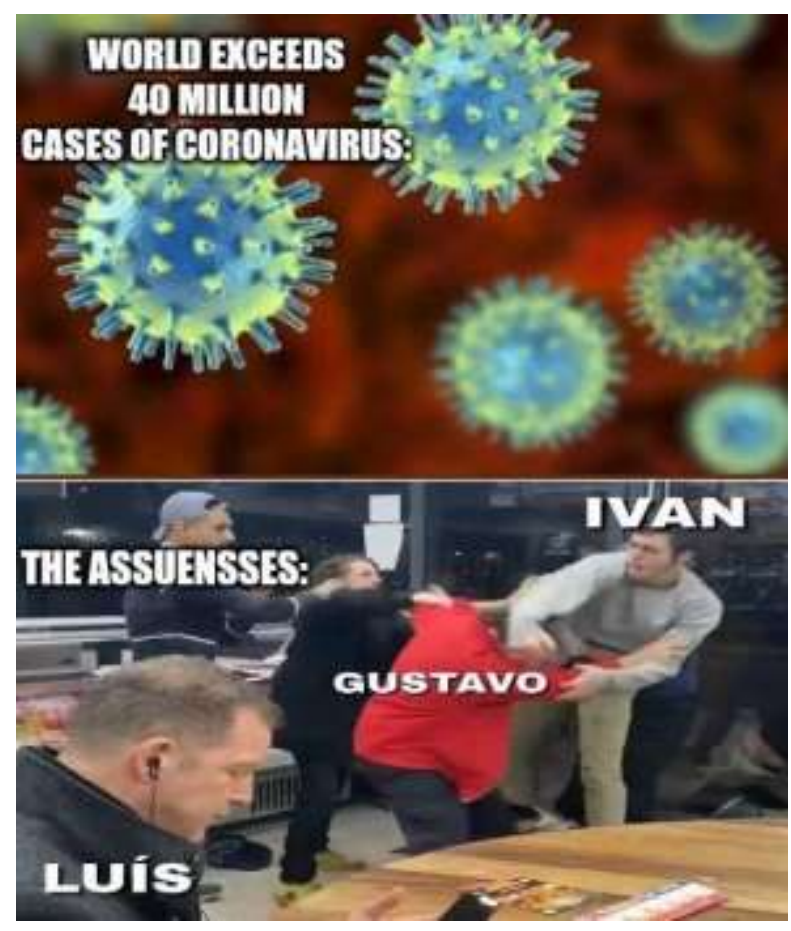

Fonte: Produção dos alunos (2020).

O meme produzido por Pedro confronta dois conteúdos de expressiva repercussão na época em que essas atividades foram desenvolvidas: a pandemia da Covid-19 e as eleições municipais de 2020. Para a construção composicional, o aluno fez a associação entre duas imagens diferentes que se hibridizaram para expressar o seu projeto de dizer. A imagem superior é um desenho do novo coronavírus, responsável pela pandemia da Covid-19, e a segunda imagem, escolhida pelo aluno, é a cena de um homem que se mantem indiferente durante uma briga em uma lanchonete.

As legendas (estilo verbal), em língua inglesa, atribuem um novo contexto às imagens com a intenção de provocar discussões muito pertinentes para a realidade que a cidade estava vivenciando. Para o autor do meme da figura 5, enquanto o mundo excedia os 40 milhões de casos de Coronavírus, os assuenses estavam "brigando" na disputa das eleições municipais, ignorando dado anterior. Esse discurso de Pedro, a partir de questões e situações vivenciadas na sociedade e que são problematizadas em sala de aula, faz-nos lembrar Masetto (1997, p. 35), quando afirma que:

Quando o aluno percebe que pode estudar nas aulas, discutir e encontrar pistas e encaminhamentos para questões de sua vida e das pessoas que constituem seu grupo vivencial, quando seu dia-a-dia de estudos é invadido e atravessado pela vida, quando ele pode sair da sala de aula com as mãos cheias de dados, com contribuições significativas para os problemas que são vividos "lá fora", este espaço se torna espaço de vida, a sala de aula assume um interesse peculiar para ele e para seu grupo de referência. 
O meme produzido por Pedro cumpriu duas funções: sintetizou a problemática e, ao mesmo tempo, incitou discussões a respeito de duas situações críticas vivenciadas naquele momento. Primeiramente, a prioridade que se deu às campanhas eleitorais, ao ponto de desprezar os perigos iminentes do novo coronavírus. Nas discussões realizadas no grupo de WhatsApp, os alunos chegaram a dizer que a população estava começando a desacreditar na Covid porque a mídia havia deixado de informar sobre novos casos de contaminação.

De acordo com os alunos, parece ter ocorrido um afrouxamento nas recomendações e restrições quanto à pandemia. Todo aquele medo, pressão, proibição davam lugar às grandes aglomerações em convenções de partidos, multidões em caminhadas e carreatas, abraços e apertos de mãos. Mas além da crítica ao descaso com pandemia em função das campanhas eleitorais, Pedro nos mostrou, por meio desse meme, uma outra situação revelada na segunda imagem: a banalização no pleito eleitoral.

Podia-se comparar ao clima de um jogo de futebol. Os eleitores se dividiam entre duas cores: azul e vermelho. O azul, que identificava o partido do candidato Ivan Lopes Júnior (REPUBLICANO), e o vermelho, Dr. Gustavo Soares (PL). Muito embora houvesse um terceiro candidato, Luis Oliveira (PSC), este, na visão dos eleitores assuenses, estava praticamente fora da disputa porque, segundo sondagens, enquetes virtuais e pesquisas realizadas para o pleito eleitoral da cidade, não havia a mínima chance de ele se eleger - um cenário muito bem ilustrado pela imagem escolhida pelo aluno Pedro.

\subsection{MEME SOBRE PRÁTICAS ANTIÉTICAS NAS CAMPANHAS ELEITORAIS}

A disputa era acirrada entre os dois candidatos a prefeito da cidade, que produziam discursos inflamados em seus palanques, ataques aos adversários nos debates, difamação e propagação de fake news em redes sociais. Além dos ataques e discurso de ódio, outro aspecto em que a falta de ética também se manifestou nas campanhas eleitorais foi mostrada pelo aluno Marcos em um meme conhecido nas redes sociais como Drift. 
Figura 6 -Meme Drift.

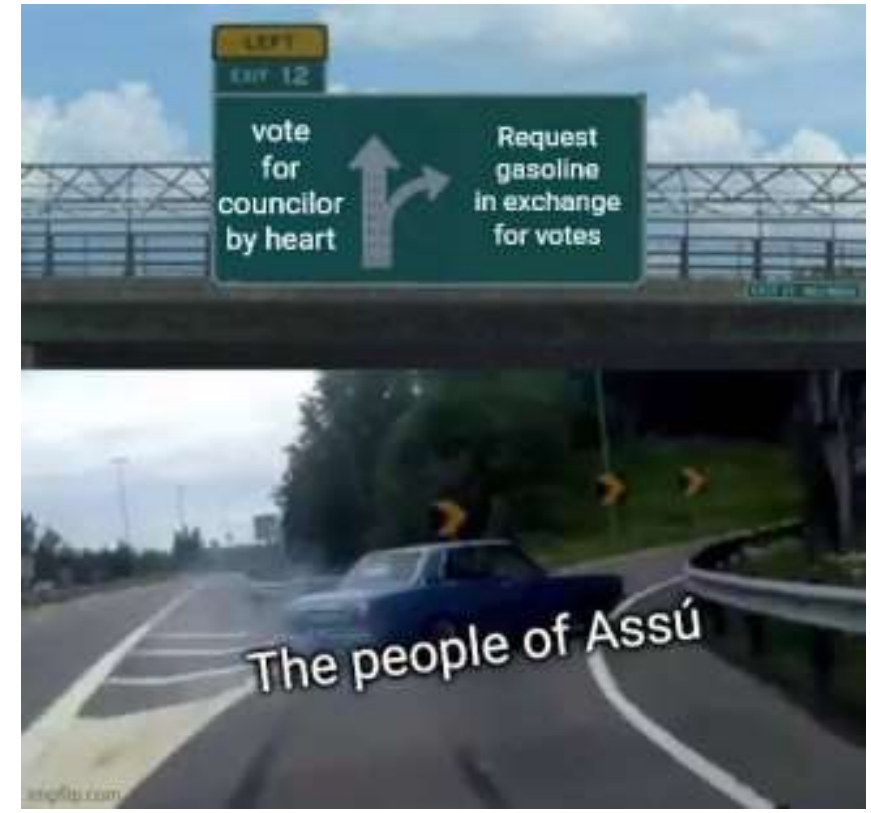

Fonte: Produção dos alunos (2020).

A imagem escolhida pelo aluno para a construção composicional do meme da figura 6 é uma técnica radical de direção chamada drift, que consiste em contornar curvas deslizando a traseira do carro. Na imagem, podemos observar um caminho reto e um desvio à direita. Esse meme é sempre utilizado quando se há um caminho a seguir e a opção de desvio por meios ilegais. No caso desse meme, na linha reta temos como indicação vote for councilor by heart (vote de coração para vereador) e, no desvio, Request gasoline in exchange for Votes (Peça gasolina em troca de votos). O carro que se desvia para a direita, de acordo com o produtor do meme, representa os eleitores da cidade de Assú.

O tema abordado pelo aluno Marcos é um dos assuntos mais polêmicos tratados em períodos eleitorais: a compra de voto, uma prática antiética bastante recorrente em parte do eleitorado. Para os jovens envolvidos em nossa pesquisa, é muito comum ouvir falar de alguém que trocou o voto por saco de cimento, tijolos, gasolina entre outras mercadorias, prática essa que minimiza a importância do ato, às vezes naturalizada em determinados locais. O aluno Marcos e os seus colegas de sala demonstraram ser conscientes de que tanto vender quanto comprar votos é uma prática antiética e ilegal.

De acordo com Silva (2016, p. 349), “Os memes podem também instaurar uma reflexão, podem questionar uma realidade, problematizar uma situação”. E isso parece estar relacionado ao conteúdo temático, com a esfera da atividade humana a que se associa o produtor de um meme. 
Quando analisamos esses trabalhos e a espontaneidade com que os alunos expuseram suas opiniões a partir dos memes, lembramos Shifman (2014, p. 123): "a criação de memes é uma rota acessível, barata e agradável para expressar as suas opiniões políticas. Como resultado, qualquer evento importante dos últimos anos tem gerado um fluxo de memes".

Assim, falar de política partidária em sala de aula tem sido um desafio cada vez maior para a escola devido à falta de comportamento ético no cenário da política, um assunto que exige muito critério e cuidado, além de muita criatividade. Muitos jovens ainda não têm uma dimensão bem definida de sua participação na política. Eles se deixam pensar que a sua responsabilidade é apenas votar, o que na verdade não é, dado o papel importante nesse processo, além do voto.

Como é dever da escola preparar os jovens para a vida em sociedade, trabalhar esse tipo de assunto em sala de aula, por meio da problematização, é fundamental e ainda mais quando a iniciativa parte dos alunos. Se a escola prepara o estudante para a vida, não precisamos discutir a necessidade de se trazer à sala de aula assuntos que estão presentes no cotidiano dos jovens cidadãos. A esse respeito, Lima e Mendes (2020, p. 196) afirmam que:

\begin{abstract}
é necessário assumir que a aprendizagem de língua inglesa se faz por meio da problematização de temas polêmicos e contemporâneos, reivindicando uma concepção de escola pública enquanto espaço de transformação. Assim, o ensino de inglês passa a se comprometer com a promoção de experiências textuais que constroem relações sociais, por meio de signos, discursos, textos, e se distancia do ensino de um código linguístico distante de contextos comunicativos experienciados pelos alunos.
\end{abstract}

Com base nesses trabalhos produzidos pelos alunos, podemos observar que a escolha por trabalhar os memes para explorar essas práticas de letramentos em aulas de língua inglesa trouxe aprendizagem significativa. Essa junção possibilitou aproximação do idioma com o aluno, uma vez que o inglês foi empregado em situações reais de seu cotidiano, com um dos gêneros textuais mais utilizados pelos jovens na comunicação em redes sociais.

Além desse atrativo, a criatividade, o contexto e a leitura deram a conotação de um inglês fácil e acessível, aumentando a capacidade de compreensão das legendas, o que dispensou o uso de dicionários e tradutores nas leituras e discussões dos textos. Além disso, os memes, como qualquer outro gênero, nasce mediante necessidade de comunicação, demostrando ser uma forma para criticar e manifestar opiniões sobre assuntos reais do cotidiano, favorecendo uma postura crítica e analítica diante de fatos e informações.

Entretanto, esse tipo de texto digital atende bem as necessidades de comunicação, por sua forma espontânea, linguagem acessível a todos, a capacidade de sintetizar e tratar 
assuntos polêmicos com naturalidade, de ser recriado por qualquer um e a qualquer momento e entre outros aspectos anteriormente citados neste trabalho. A sua junção com a verbalização em inglês se comprovou como uma excelente proposta de letramentos em aulas de língua inglesa.

\section{CONSIDERAÇÕES FINAIS}

Esta pesquisa é fruto de uma reflexão sobre a problemática que envolve o ensino de idiomas, sobretudo de língua inglesa, em escolas públicas brasileiras e das exigências postas diante de um mundo globalizado, fatores esses que refletem nossa prática diária como professor na educação básica, causando-nos uma preocupação com a qualidade e com os resultados em sala de aula.

Nosso primeiro passo, com a intensão de satisfazer os objetivos traçados, foi estudar a problemática que envolve o ensino de língua inglesa nas escolas públicas brasileiras e, para isso, dialogamos com autores que se pautam sobre o ensino de Língua Estrangeira Moderna (LEM) e com os principais documentos oficias da educação no Brasil. Com essas referências geradas, partimos para o desenvolvimento de uma intervenção em sala de aula, para propor alternativas através da implementação de uma intervenção pedagógica de letramento e extrapolar dificuldades de aprendizagem em uma turma de primeira série do ensino médio, na disciplina de língua inglesa, em uma escola pública do Rio Grande do Norte no Brasil.

O trabalho consistiu na realização de atividades de leitura e produção textual a partir do gênero meme. Os alunos produziram, leram, discutiram memes, envolvendo assuntos que repercutiram nos mais diversos meios de comunicação, sobretudo nas redes sociais, no período em que as atividades foram desenvolvidas.

Logo após, avaliamos o trabalho com o gênero meme enquanto elemento de multiletramento capaz de promover importantes reflexões, contribuindo expressivamente para o aprendizado em sala de aula, nos mais diversos contextos de interação, constituição dos discursos e inclusão social. Os alunos conseguiram, tendo consciência do potencial de sentidos a que esses textos se prestam, utilizar a língua inglesa em situações reais de uso no cotidiano, discutir assuntos polêmicos com espontaneidade e humor, além de se posicionar de forma crítica e analítica diante de fatos e informações.

Observamos, tanto na teoria quanto na prática, a importância de um ensino de inglês que interage por meio de conteúdos e conceitos de uso diário, porque é um ensino voltado 
para os seus interesses e que leva em consideração aquilo que os estudantes sabem sobre o idioma.

Além disso, compreendemos que a língua inglesa precisa ser utilizada, de fato, como uma porta de entrada para que os estudantes tenham acesso ao mundo globalizado como um cidadão crítico, engajado e participativo na sociedade. Assim, a língua deixa de ser apenas um instrumento de comunicação e os alunos passam a "fazer uso da linguagem para agir no mundo social" (BRASIL, 1998, p. 38).

Todavia, o resultado dessa intervenção pedagógica de letramento com o gênero meme confirmou o que discutimos em conexão com alguns autores. Assim, como qualquer outro gênero discursivo que nascem mediante a necessidade de comunicação, os memes demostraram ser uma excelente opção quando queremos criticar, elogiar, debochar, reivindicar, porque são formas práticas e compactas para se fazer isso.

Portanto, aos que desejam utilizar os memes para fins didáticos, podemos dizer que este trabalho, com estudantes de ensino médio, a partir desse gênero digital, mostrou-nos possibilidades e procedimentos metodológicos de fácil execução, podendo serem usados com efetividade em outros componentes curriculares e em diferentes modalidades de ensino. Pois, são práticas que visam sempre essa possibilidade de um sujeito enquanto ator de uma sociedade.

Consideramos também os memes como um recurso metodológico versátil e inesgotável. Com eles, podem-se abordar assuntos da atualidade, relações internacionais, questões emocionais, conceitos históricos, física, astronomia, comunismo, socialismo e entre outros, por meio de uma linguagem sintética e bem humorada.

No entanto, a título de sugestão e alerta aos professores e pesquisadores, há outros aspectos relevantes em relação aos memes com rico potencial didático. Assim como eles podem favorecer a interação em sala de aula, também podem provocar discursos ofensivos e discórdias. Muitas vezes, o que se faz para provocar o riso, pode expor pessoas em situações constrangedoras ou ridículas e da mesma forma que ele nos atualiza com importantes notícias podem também reproduzir uma desinformação.

Por isso, cabe aos professores ou pesquisadores ter os devidos cuidados e orientações na hora da seleção ou produção desse tipo de textos em sala de aula. Caso contrário, esse aspecto obscuro dos memes poderá ser, em vez de solução, um problema que acarretará em sérias consequências, entre elas a desmotivação do aluno pela aprendizagem.

Portanto, neste percurso, a pesquisa nos mostrou que, em meio a tantos impactos positivos, o uso didático desses gêneros nas aulas de língua inglesa configurou-se como uma 
estratégia de ensino-aprendizagem produtiva. Forneceram, simultaneamente, um dos melhores retratos de valores e problemas de uma sociedade, mas, ao mesmo tempo, provocaram o riso e a diversão, proporcionando, assim, prazer e, consequentemente, o interesse pela aprendizagem através de uma formação crítica.

\section{REFERÊNCIAS}

BAKHTIN, M. Estética da criação verbal. Os gêneros do discurso. 2. ed. São Paulo: Martins Fontes, 1997.

BLACKMORE, S. The Meme Machine. Oxford: Oxford University Press, 2000.

BRASIL. Base Nacional Comum Curricular: educar é a base. Comitê Gestor da Base Nacional Comum Curricular e reforma do Ensino Médio. Secretaria de Educação Básica. Brasília: Ministério da Educação, 2018.

BRASIL. Lei de Diretrizes e Bases da Educação Nacional. Lei $\mathbf{n}^{\mathbf{0}}$ 13.415/2017, de 13 de fevereiro de 2017, Altera a Lei $n^{\mathbf{0}}$ 9.394, de 20 de dezembro de 1996. Disponível em: http://www.planalto.gov.br/ccivil_03/_ato2015-2018/2017/lei/L13415.htm. Acesso em: 5 fev. 2020.

BRASIL. Ministério da Educação. Secretaria da Educação Básica. Base nacional Comum Curricular. Brasília, 2017.

BRASIL. Secretaria de Educação Fundamental. Parâmetros curriculares nacionais: primeiro e segundo ciclos do ensino fundamental: língua portuguesa. Brasília: MEC/SEF, 1998.

BRITISH COUNCIL. O ensino de inglês na educação pública brasileira: elaborado com exclusividade para o British Council pelo Instituto de Pesquisas Plano CDE. São Paulo, SP:

British Council Brasil, 2015. Disponível em https://www.britishcouncil.org.br/sites/default/files/estudo_oensinodoinglesnaeducacaopub licabrasileira.pdf: Acesso em: 10 dez. 2019.

BURNS, A. Action research in second language teacher education. In: RICHARDS, Jack C. The Cambrige guide to research in Language teaching and education. New York: Cambridge University Press, 2009ª , p. 289-297.

CAVALCANTE, M. M.; OLIVEIRA, R. L. O recurso aos memes em diferentes padrões de gêneros à luz da Linguística Textual. Revista do Programa de Pós-Graduação em Letras da Universidade de Passo Fundo, [s. l.], v. 15, n. 1, p. 8-23, 2019.

DAWKINS, R. O gene egoísta. São Paulo: Companhia das Letras, 1976. (Tradução de Rejane Rubino)

FARACO, A. (org). A relevância Social da Linguística: Linguagem, Teoria e Ensino. Parábola: São Paulo. 2007.

FLICK, U. Desenho da pesquisa qualitativa. Coleção Pesquisa Qualitativa (Coordenação de Uwe Flick). Porto Alegre: Bookman, Artmed, 2009.

KEMMIS, S.; McTAGGART, R. Cómo planificar la investigación-acción. Barcelona: Laertes, 1988.

LIMA, G. O. S; CASTRO, L. G. F. Meme digital: artefato da (ciber)cultura. Con(textos) Linguísticos, v.10, n. 16, p. 38-51, 2016. 
LIMA, S. C.; MENDES, E. S. S. Whatsapp e fake news no ensino de língua inglesa em uma escola pública do interior do estado do Ceará. Texto livre, Belo Horizonte, v. 13, p. 182200, 2020.2 Disponível em: https://periodicos.ufmg.br/index.php/textolivre/article/view/24889/19656. Acesso em: 22 dez. 2020.

LIMA-NETO, V. Um estudo da emergência de gêneros no facebook. Tese (Doutorado em Linguística) - Programa de pós-graduação em Linguística da Universidade Federal do Ceará, Fortaleza, 2014.

MARTINO, L. M. S. Memes e virais, replicações e cultura. In: MARTINO, Luís Mauro Sá. Teoria das mídias digitais: linguagens, ambientes, redes. 2. ed. Petrópolis/RJ: Vozes, 2015.

MASETTO, M. T. Didática: a aula como centro. 4. ed. São Paulo: FTD, 1997.

PAIVA, V. L. M. Manual de pesquisa em estudos linguísticos. São Paulo: Parábola, 2019, 157 p. v. 1.

PRENSKY, M. Digital Native, digital immmigrants. Digital Native immigrants. On the horizon, MCB University Press, v. 9, n. 5, October, 2001. Disponível em: http://www.marcprensky.com/writing/Prensky\%20-

\%20Digital\%20Natives,\%20Digital\%20Immigrants\%20-\%20Part1.pdf. Acesso em: 1 mar. 2020.

RAJAGOPALAN, K. "Vencer barreiras e emergir das adversidades com pleno êxito, sempre com pé no chão. In: Lima, Diógenes Cândido de. (org.). Inglês em escolas públicas não funciona: uma questão, múltiplos olhares. São Paulo: Parábola, 2011.

RAJAGOPALAN, K. A geopolítica da língua inglesa e seus reflexos no Brasil: Por uma política prudente e propositiva. In: LACOSTE, Y. (org.); RAJAGOPALAN, K. A geopolítica do Inglês. São Paulo: Parábola Editorial, 2005a. p. 135-159.

RAJAGOPALAN, K. A língua estrangeira para crianças: um tema no mínimo ambíguo. In: ROCHA, C. H.; TONELLI, J. R. A.; SILVA, K. A. (org.) Língua estrangeira para Crianças: Ensino-Aprendizagem e Formação Docente. Campinas: Pontes Editores, 2010.

RAJAGOPALAN, K. O inglês como língua internacional na prática docente. In: LIMA, Diógenes Cândido de. (Org.). Ensino e aprendizagem de língua inglesa: conversas com especialistas. São Paulo: Parábola Editorial, 2009.

RECUERO, R. Redes sociais na internet. Porto Alegre: Sulina, 2009.

ROJO, R.; BARBOSA, J. P. Hipermodernidade, multiletramentos e gêneros discursivos. São Paulo: Parábola Editorial, 2015.

SANTOS, A. M. B. et al. Conexões entre letramento e literatura digital. In: Linguagem em foco. Revista do programa de Pós Graduação em Linguística Aplicada UECE. Ceará: v. p. 117-129, 2017.

SAVIANI, D. Educação Escolar, Currículo e Sociedade: o problema da Base Nacional Comum Curricular. Revista Movimento, Universidade Federal Fluminense, ano 3, n. 4, p. 54-84, 2016.

SHIFMAN, L. Memes in digital culture. Massachusetts: MIT Press, 2014.

SILVA, A. A. Memes virtuais: gênero do discurso, dialogismo, polifonia e heterogeneidade enunciativa. Revista Travessias, v. 10, n. 3, p. 341-361, 2016. Disponível em: http://erevista.unioeste.br/index.php/travessias/article/view/15111/10559. Acesso em: 20 jul. 2020. 
SOUZA, C. F. Memes: formações discursivas que ecoam no ciberespaço. VÉRTICES, Campos dos Goytacazes, v. 15, n. 1, p. 127-148, 2013.

\section{Autores}

\section{Ananias Agostinho da Silva}

Universidade Federal Rural do Semi-Árido

Doutorado em Estudos da Linguagem

Programa de Pós-Graduação em Ensino

Ensino de língua portuguesa; Linguística Textual ananias.silva@ufersa.edu.br

Rubens Oliveira Dantas

Professor da Rede Pública do Estado do RN

Mestrado em Ensino POSENSINO

Linguagens

rubens0307@hotmail.com 